\title{
Impact of Ash-Fertilization and Soil Preparation on Soil Respiration and Vegetation Colonization on Cutaway Peatlands
}

\author{
Niko Silvan ${ }^{*}$, Jyrki Hytönen ${ }^{2}$ \\ ${ }^{1}$ Natural Resources Institute Finland, New Technologies Development, Parkano Unit, Parkano, Finland \\ ${ }^{2}$ Natural Resources Institute Finland, Natural Resources and Bioproduction, Kannus Unit, Kannus, Finland \\ Email: "niko.silvan@luke.fi
}

Received 10 March 2016; accepted 5 June 2016; published 9 June 2016

Copyright (C) 2016 by authors and Scientific Research Publishing Inc. This work is licensed under the Creative Commons Attribution International License (CC BY). http://creativecommons.org/licenses/by/4.0/ (c) (i) Open Access

\begin{abstract}
As a result of several decades of peat extraction, the area of cutaway peatlands in Finland totals ca. 50,000 ha. Furthermore, some $2000-3000$ ha of peatlands are abandoned annually from active peat extraction. Forestry is considered to be their main after-use option. However, since cutaway peat is generally rich in nitrogen, but poor in phosphorus and potassium, soil amelioration measures are needed for successful vegetation and afforestation. Soil preparations bringing mineral soil into peat surface or recycling of ash containing $P$ and $K$ are alternative ways for soil amelioration. We studied the initial effects of soil preparation and ash fertilization on soil $\mathrm{CO}_{2}$-effluxes and colonisation of cutaway peat by vegetation. Oppositely to the previous studies, this study shows that carbon released from the residual peat may be so high that the ash-fertilized cutaway peatlands still act as sources of carbon even after afforestation. However, even though the $\mathrm{CO}_{2}$-effluxes following ash fertilization or soil preparation may occasionally exceed the carbon sequestration into growing tree stands, afforestation mostly compensates the $\mathrm{CO}_{2}$-effluxes if also we take into consideration the below-ground biomass. In conclusion, our study shows that although ash-fertilization enhances the $\mathrm{CO}_{2}$-effluxes into the atmosphere, it has beneficial effects on the environment by enabling rapid colonisation of vegetation on these sites which would remain vegetationless for decades without soil amelioration.
\end{abstract}

\section{Keywords}

Soil Amelioration, $\mathrm{CO}_{2}$-Efflux, Ground Vegetation, Cutaway Peatlands

\footnotetext{
${ }^{*}$ Corresponding author.
} 


\section{Introduction}

The most important producers and users of energy peat within the European Union are Finland, Ireland, Sweden, Latvia, Lithuania, Estonia and Scotland. Peat has a substantial share, 4\% - 7\%, of total energy consumption in Finland and Ireland, and 1.2\% in Estonia and 0.6\% in Sweden [1] [2]. As an indigenous fuel, peat has a considerable effect on regional policy in peat producing countries since it increases local employment and the reliability of the energy supply [1] [3]. Presently, fuel and horticultural peat combined is extracted on ca. 70,000 hectares in Finland [2] and it is estimated that additionally 63,000 ha on new peat harvesting areas are needed by 2020 [4]. In Estonia pet production area is 20,500 ha [5]. As a result of the peat extraction lasted for many decades, the area of cutaway peatlands totals in Finland ca. 50,000 ha and in Estonia 9400 ha [6]. In Finland some 2000 - 3000 ha of cutaway peatlands are abandoned annually from active peat extraction. In Ireland approximately 50,000 ha of cutaway peatlands are likely to become available for afforestation over the next 30 years [7]. Forestry is usually considered to be the main after-use option for cutaway peatlands in Finland [8], Sweden [9] and Ireland [7] and it has been studied also in the Baltic countries [10]. Also production of bioenergy could be continued economically via growing energy crops with woody species, e.g. growing downy birch with short rotations [11]. However, some sites can be also used for agriculture, restoration or waterfowl sanctuaries [8].

Cutaway peatlands differ considerably from forested peatland sites in their soil properties [12]. They are characterized by variable peat thickness, low $\mathrm{pH}$ and high nitrogen, but low phosphorus and potassium concentrations [10] [12] [13]. The large nitrogen store in the remaining peat layer is an advantage. However, nitrogen is bound in the organic matter in the peat and becomes available to plants via mineralisation of that organic matter. The vegetation succession on extracted peatlands after abandonment is often a long-lasting, slow and irregular process because of the absence of viable propagules and the unfavourable conditions for plant growth [14]. Nutritional problems may be encountered besides vegetation succession when afforesting the cutaway peatlands; consequently, the success of afforestation will depend in many cases on soil amelioration and fertilization [10] [13] [15]-[18]. Thus, fertilization and soil preparation are also the most important factors affecting the biomass production of short-rotation tree plantations on cutaway peatlands [19] [20]. The mineral nutrient stores in the mineral soil beneath the peat layer may compensate for fertilization requirements. According to Aro [21], roots of 17-year-old silver birch stands have a mean root penetration of $6-15 \mathrm{~cm}$. Thus, even when peat layer is rather shallow, fertilization or soil preparation which brings mineral soil onto top of the peat is needed to ensure the balanced nutrition of plants.

Consumption of primary biomass for energy production generates increasing quantities of wood ash. In Finland, the total amount of wood ash produced annually by the forest industry is estimated to be 200,000 300,000 tonnes. Large amounts of wood ash have also been produced in recent decades in other countries, especially in Scandinavia and North America [22]. Wood ash contains many of the essential nutrients required for plant growth, except, notably, nitrogen $(\mathrm{N})$. Wood ash may therefore have potential as a fertiliser for cutaway peatlands where bottom peat is especially low in phosphorus (P) and potassium (K). Long-term positive effects of wood ash on the growth of conifers on forested peatlands have been reported in many studies [23]-[26]. Often peat and wood are burned as a mixture resulting in mixed peat and wood ashes. An estimated 300,000 - 400,000 tonnes of peat ash and mixed peat and wood ash are produced annually [22]. Recycling of the nutrients contained in peat ash, now mostly disposed of as waste could be an interesting alternative for improving the nutritional status of soils.

The positive and crucial effects of wood ash on the nutrient status of peatland forests, biological activity in peat and the growth of trees have been known for a long time [27]-[29]. However, the enhancement of biological activity in peat will also lead to increased carbon release into the atmosphere [30]. Already when peat extraction has ceased the non-vegetated residual peat decomposes aerobically and thus increases the carbon release [31]. However, when restoration is successful developing mire vegetation fixates and accumulates carbon compensating considerable part of the $\mathrm{CO}_{2}$-effluxes [31]. The afforestation of cutaway peatlands could also be seen as a possible way to sedate soil carbon release into the atmosphere due to an increase in sequestration of atmospheric carbon into the growing tree biomass [32]. Also afforestation with fast-growing short-rotation deciduous tree species for energy could improve the carbon balance. At the early stages of afforestation of cutaway peatlands the development of ground vegetation has a marked effect on the carbon balance [18] [33]. In fact, soil amelioration and fast development of vigorous ground vegetation may have a major role in the carbon balance of afforested cutaway peatlands during the first couple of years after afforestation [18]. In this study we ex- 
amined the short-term effect (two - three years) of ash-fertilization and soil preparation on soil respiration and ground vegetation colonization on a cutaway peatland prepared for short-rotation energy tree plantations.

\section{Materials and Methods}

\subsection{Study Site and Arrangements}

The study was carried out during 2012-2014onPiipsannevacutaway peatland at Haapavesi, central Finland $\left(64^{\circ} 06^{\prime} \mathrm{N}, 25^{\circ} 36^{\prime} \mathrm{E}\right)$ (Figure 1). Peat production had ceased on the site in 2010, one year before the establishment of the experiment. The establishment started in August 2011 by ditching and soil preparation and continued in March 2012 by ash-fertilization. The soil amelioration treatments studied were: 1) control, 2) ash-fertilization, 3) mounding, 4) mounding, levelling and ash-fertilization and 5) mounding and ash-fertilization (Figure 2). The former peat production strips were first levelled with normal peat production machinery (except control) and followed by mounding or ash-fertilization. Mounding was done by excavator and created mounds on top of the peat consisting of mineral soil. During the summer 2013 seven different short-rotation energy tree species were either sown or planted onto the mounded or ash-fertilized areas as a split-plot study (Figure 2). Also one uncultivated control treatment was included into the study (Figure 2).

Wood originated ash (FA Forest Ecolan) was spread in $23^{\text {rd }}$ March 2012 onto the snow cover of $25-40 \mathrm{~cm}$ at intensity of ca. 3.3 tha $^{-1}$ as dry matter. Two samples were taken for determining the nutrient contents of the ash. The samples were analyzed in the laboratories of Kannus and Vantaa Research Stations of the Finnish Forest Research Institute (presently Natural Resources Institute Finland). The analyzed means forthe nutrient contents were: P $9.0 \mathrm{~g} \cdot \mathrm{kg}^{-1}$, K $35.0 \mathrm{~g} \cdot \mathrm{kg}^{-1}$, Ca $135.0 \mathrm{~g} \cdot \mathrm{kg}^{-1}$, Mg $17.2 \mathrm{~g} \cdot \mathrm{kg}^{-1}$, Mn $6.9 \mathrm{~g} \cdot \mathrm{kg}^{-1}$, Fe $24.6 \mathrm{~g} \cdot \mathrm{kg}^{-1}$, Zn $1.5 \mathrm{~g} \cdot \mathrm{kg}^{-1}$, $\mathrm{Cu} 0.1 \mathrm{~g} \cdot \mathrm{kg}^{-1}$.

Peat depth was measured from 20 - 92 points on each treatment, and overall from 377 points. The depth of the residual peat layer (well-humified Carex-peat) on the study area was generally very low (Table 1). Composite

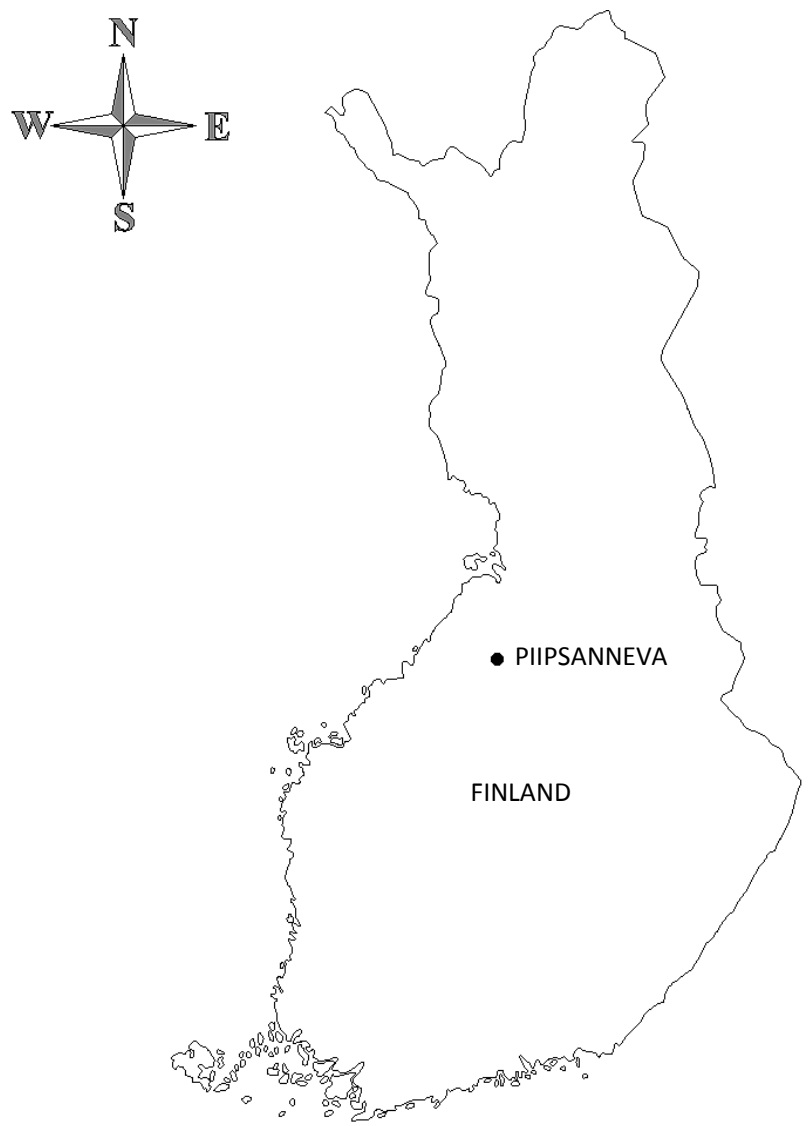

Figure 1. Location of the study site. 


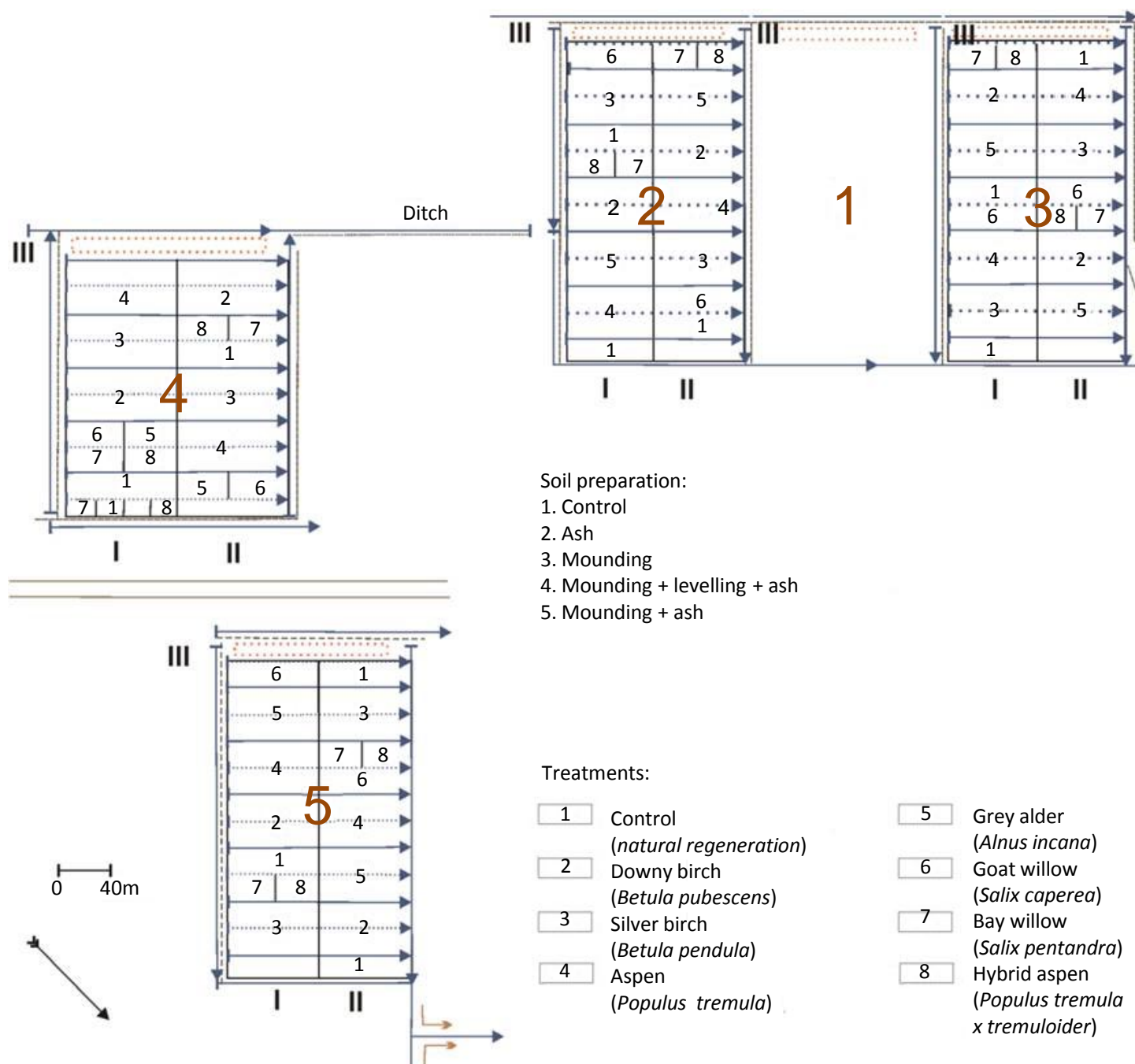

Figure 2. Study site and different soil amelioration treatments at Piipsanneva.

Table 1. Ash content and peat depth of the different soil amelioration treatments at Piipsanneva.

\begin{tabular}{ccccc}
\hline Treatment & Ash \% & \multicolumn{3}{c}{ Peat depth, cm } \\
\cline { 2 - 5 } & & Mean & Min & Max \\
\hline Control & 47 & 23 & 18 & 28 \\
Ash-fertilization & 34 & 24 & 8 & 50 \\
Mounding & 64 & 23 & 5 & 58 \\
Mounding + levelling + ash & 79 & 24 & 0 & 42 \\
Mounding + ash & 52 & 12 & 0 & 45 \\
\hline
\end{tabular}

soil samples were taken from each of the soil amelioration treatments from the 0 - $10 \mathrm{~cm}$ peat layer in May 2012. The ash content of the samples was determined from the analyses of loss on ignition $\left(550^{\circ} \mathrm{C}\right)$ (Table 1$)$.

\subsection{Weather Characteristics during the Study Period}

The thermal growing season started in early May and lasted until the beginning of October during study years 2013 and 2014. The mean seasonal (May-October) temperatures at Piipsanneva were higher in both study years than the long term average of $1984-2014$ (12.1, 11.0 and $10.5^{\circ} \mathrm{C}$, respectively) (Figure 3). The cumulative 


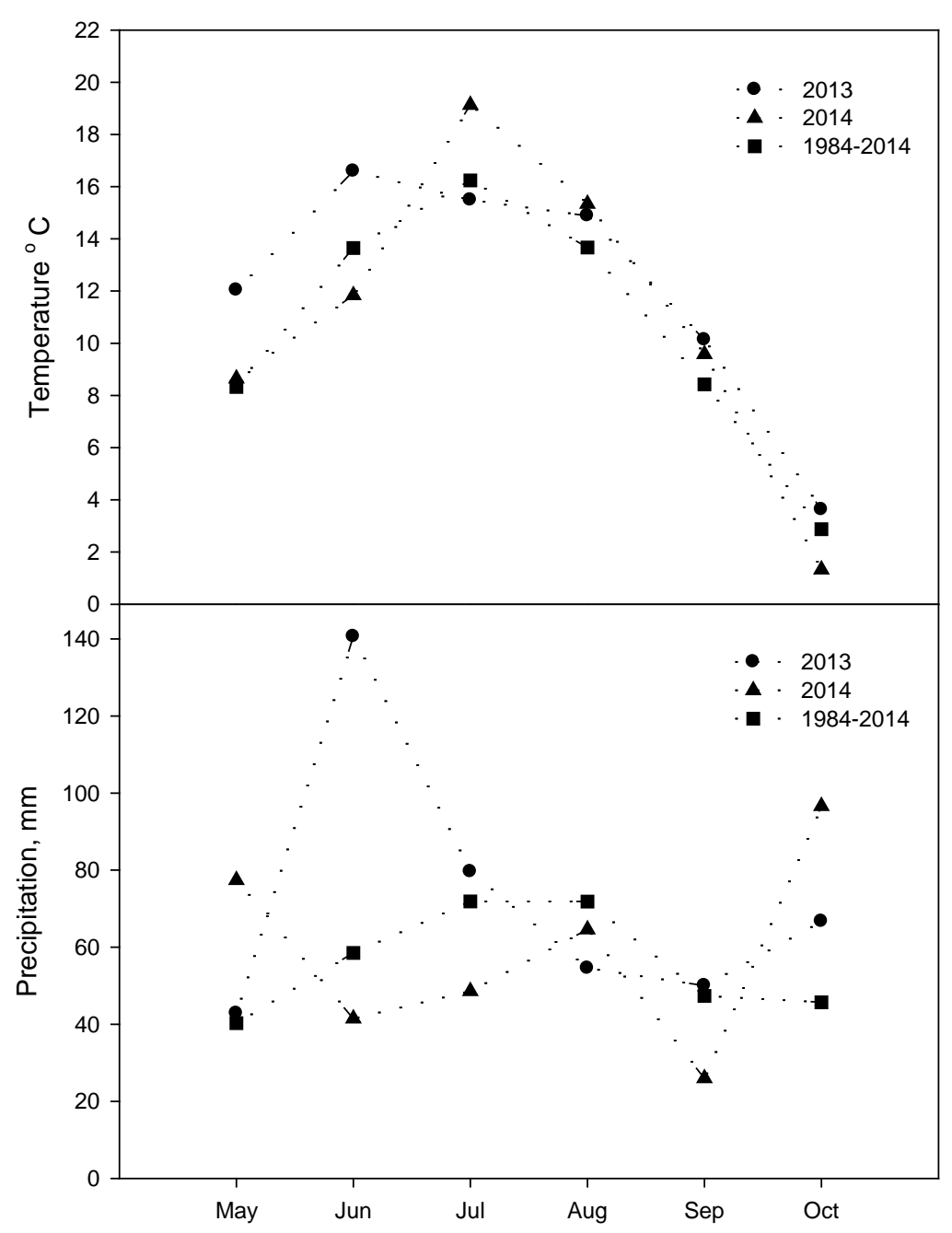

Figure 3. Mean air temperature and monthly precipitation at Piipsanneva from March to October during 2013-2014 and the 30-year average (1984-2014).

precipitations during May-October were also slightly higher than the long-term average of 1984-2014 (336 mm) in both study years 2013-2014 (434 and 355 mm, respectively) (Figure 3). However, especially the monthly precipitation in June 2013 was clearly higher than the monthly long term average of 1984-2014 (Figure 3).

\subsection{Ground Vegetation Monitoring}

An inventory of mosses and lichens (bottom layer) and vascular plants (field layer) was taken in September 2012-2014 by estimating the coverage of each species as a percentage within six square-shaped $1 \mathrm{~m}^{2}$ plots for each five soil amelioration treatment. The scale used for the estimation was $<1 \%$ (marked as + ), then $1 \%$ intervals to $100 \%$. Nomenclature of the ground vegetation follows Hämet-Ahti et al. [34] for vascular plants, Koponen [35] for bryophytes and Jahns [36] for lichens.

\section{4. $\mathrm{CO}_{2}$-Efflux Measurements}

Three aluminium collars $\left(0.07 \mathrm{~m}^{-2}\right)$ with a $25 \mathrm{~cm}$ long sleeve were set into the soil of each soil amelioration treatment, i.e. 15 collars altogether, in summer 2012 prior to $\mathrm{CO}_{2}$-efflux measurements. Instantaneous $\mathrm{CO}_{2}$-effluxeswere measured ca. monthly during growing seasons (May-October) 2013-2014 using the closed chamber method, which employs a portable infra-red $\mathrm{CO}_{2}$-analyzer (EGM-4, PP-Systems Inc.) over a measurement period of ca. 80 seconds [37]. $\mathrm{CO}_{2}$-effluxes were calculated automatically via the built-in EGM program, but all 
measurements were checked and corrected afterwards if some anomalies were observed. The existing vegetation was removed prior to $\mathrm{CO}_{2}$-efflux measurements, and the observed regrowth was clipped before every measurement occasion. Thus, only soil heterotrophic respiration (SR) without autotrophic vegetation respiration was measured. Soil temperatures at $5 \mathrm{~cm}$ below the soil surface (T5) were measured manually simultaneously with the SR measurements to relate the fluxes to the prevailing environmental conditions. In addition to manual T5 measurements, $\mathrm{T} 5$ was also monitored continuously at all soil amelioration treatments. The soil temperature data was collected automatically bihourly using miniature temperature data loggers (i-button, Dallas Semiconductor Corp.) inserted inside the aluminium collars. T5 was chosen for the driving variable in SR model building since it was observed to be the best single depth for predicting $\mathrm{CO}_{2}$-effluxes [38] [39].

\subsection{Statistical Analyses}

The estimated annual SR was based on several individual observations in space and time during two seasons in 2013-2014. SR is closely dependent on soil temperature. Thus, to simulate seasonal (May-October) SR we used bihourly soil temperature ( $5 \mathrm{~cm}$ below soil surface, T5) as a driving variable to build up treatment specific regression models. In an SR model [40], we used the exponential relationship of respiration to peat temperatures at $5 \mathrm{~cm}$ below the peat surface $\left(T_{5}\right)$ :

$$
\text { Rtot }=a * x^{\left(b *\left(\left(\frac{1}{10+46,02}\right)-\left(\frac{1}{x+46,02}\right)\right)\right)}
$$

In the equation $x$ is $T_{5}$, numbers 10 and 46.02 are constants, and $a$ and $b$ are model parameters (Table 2). In SR model building, we combined the individual $\mathrm{CO}_{2}$-efflux observations from the three measurement plots of each soil amelioration treatment due to the too small size of data set for a plot-wise modeling.

Since instantaneous $\mathrm{CO}_{2}$-effluxobservations were made on the same measurement plots over a period of time, the observed responses were therefore correlated. As opposed to the analysis of variance (ANOVA), linear mixed models have been designed to handle correlated data with unequal variances from normal distributions [41]. Thus, the analyses of instantaneous $\mathrm{CO}_{2}$-effluxrates were based on fixed effects models with restricted maximum likelihood estimation method using the linear mixed procedure in SPSS Statistics ver. 22 (IBM Corp., USA). Statistical tests of model-simulated SRs and ground vegetation were made with the one-way ANOVA in SPSS Statistics ver. 22 (IBM Corp., USA). The square root transformation was applied to variables with percentage values prior to statistical tests for stabilizing the variance. Test results were considered significant when $p<0.05$.

\section{Results}

\subsection{Ground Vegetation Colonization}

All soil amelioration treatments, except mounding without ash, significantly increased the coverage of vascular plants (field layer vegetation) in comparison with the coverage on the control areas in all study years 2012-2014 ( $\mathrm{F}=3.62, p<0.05 ; \mathrm{F}=4.98, p<0.05$ and $\mathrm{F}=3.24, p<0.05$, respectively) (Figure 4, Table 3). The most intense soil amelioration treatment (mounding + levelling + ash) increased the field layer vegetation coverage most (Figure 4, Table 3). Mere mounding led to a small increase of coverage compared to control in 2012 but in 2013 and 2014mounding gave smaller coverage than control treatment (Figure 4, Table 3). The coverage of the field layer vegetation increased in all treatments including control annually. The annual increase was smallest

Table 2. Parameters for the SR models during 2013-2014.

\begin{tabular}{|c|c|c|c|c|}
\hline \multirow{2}{*}{ Treatment } & \multicolumn{2}{|c|}{2013} & \multicolumn{2}{|c|}{2014} \\
\hline & $\mathbf{a}$ & $\mathbf{b}$ & $\mathbf{a}$ & $\mathbf{b}$ \\
\hline Control & 0.109 & 342.4 & 0.089 & 234.8 \\
\hline Ash-fertilization & 0.158 & 523.1 & 0.156 & 163.1 \\
\hline Mounding & 0.165 & 415.5 & 0.120 & 218.0 \\
\hline Mounding + levelling + ash & 0.229 & 173.6 & 0.215 & 165.1 \\
\hline Mounding + ash & 0.216 & 218.9 & 0.173 & 172.5 \\
\hline
\end{tabular}




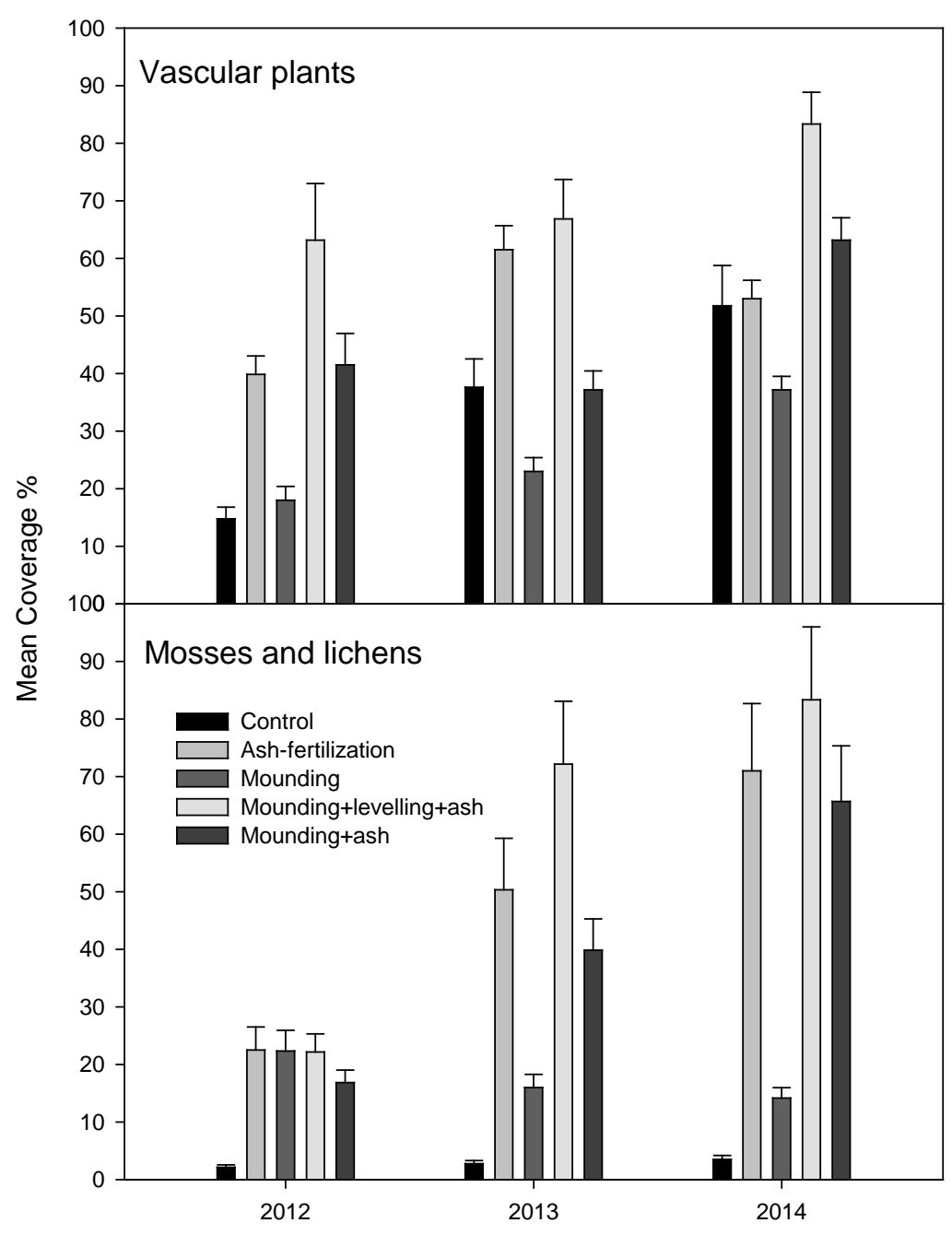

Figure 4. Mean coverage for vascular plants (field layer) and mosses and lichens (bottom layer) of the different soil amelioration treatments at Piipsanneva during 2012-2014. Vertical bars show SE for means.

in the mounded area and remained lower than in the control treatment (Figure 4, Table 3). Altogether 22 vascular plant species were recorded in the first study year 2012, in the last study year 2014 the number had increased to 29 (Table 3). However, most of the recorded vascular plant species occurred only very sporadically (Table 3). On the other hand, two dominant weed species (Alopecurus geniculatus and Equisetum arvense) formed almost $40 \%$ of the total vascular plant coverage in all treatments (Table 3 ).

As of vascular plants, all soil amelioration treatments, excluding the mere mounding, significantly increased also the coverage of mosses and lichens (bottom layer vegetation) in comparison with the coverage of on the control area in all study years 2012-2014 ( $\mathrm{F}=2.61, p<0.05 ; \mathrm{F}=5.15, p<0.05$ and $\mathrm{F}=5.85, p<0.05$, respectively) (Figure 4, Table 3). The most intensive treatment (mounding + levelling + ash) increased the coverage of mosses and lichens most, and mere mounding had the smallest effect on the bottom layer vegetation coverage (Figure 4, Table 3). The coverage of mosses and lichens in the control treatment remained very low even at the end of the third growing season (Table 3). All ash-treatments led to a coverage over $60 \%$ at the end of the study. Altogether five species of mosses and lichens were recorded during study years. The major part (almost $80 \%$ ) of the total coverage of mosses and lichens consisted of Pohlianutans in all treatments (Table 3).

\section{2. $\mathrm{CO}_{2}$-Effluxes}

The mean measure dinstantaneous $\mathrm{CO}_{2}$-effluxes for control site and the different soil amelioration treatments 
Table 3. Mean coverage (\%) of plant species in the field (vascular plants) and in the bottom layer (mosses and lichens) of the different soil amelioration treatments at Piipsanneva during 2012-2014. The coverage of $<1 \%$ is marked as + . The soil amelioration treatments were: 1) control, 2) ash-fertilization, 3) mounding, 4) mounding, levelling and ash-fertilization and 5) mounding and ash-fertilization.

\begin{tabular}{|c|c|c|c|c|c|c|c|c|c|c|c|c|c|c|c|}
\hline \multirow[b]{2}{*}{ Treatment } & \multicolumn{6}{|c|}{2012} & \multicolumn{4}{|c|}{2013} & \multicolumn{5}{|c|}{2014} \\
\hline & 1 & 2 & 3 & 4 & 5 & 1 & 2 & 3 & 4 & 5 & 1 & 2 & 3 & 4 & 5 \\
\hline \multicolumn{16}{|l|}{ Field layer } \\
\hline Agrostis capillaris & & & & & & & & & & & + & + & + & 6.7 & 4.7 \\
\hline Alopecurus geniculatus & + & 7.7 & 7.3 & 46.2 & 21.7 & 1.3 & 5.5 & 10.8 & 34.0 & 15.3 & + & 3.5 & 5.8 & 24.0 & 16.2 \\
\hline Barbarea vulgaris & + & + & + & + & 1.8 & + & + & + & + & + & + & + & + & + & + \\
\hline Bidens tripartita & + & + & 9.0 & 7.3 & 15.0 & + & + & 5.5 & 1.3 & 3.7 & + & + & 8.0 & + & 1.0 \\
\hline Carex spp. & + & + & + & + & + & + & 2.5 & 0.7 & + & 2.0 & + & 2.2 & + & + & 3.3 \\
\hline Calamagrostis purpurea & + & + & + & 1.8 & 1.2 & + & 3.0 & 1.0 & 2.8 & 2.7 & + & 8.5 & 6.7 & 4.8 & 7.7 \\
\hline Cerastium fontanum & + & + & + & + & + & + & + & + & + & + & + & + & + & + & + \\
\hline Deschampsia cespitosa & + & + & + & + & + & + & + & + & 2.0 & 6.3 & + & + & + & 6.7 & 12.7 \\
\hline Elymus repens & & & & & & + & + & + & + & 3.3 & + & + & + & + & 1.7 \\
\hline Epilobium adenocaulon & + & 10.3 & + & + & + & + & 5.7 & + & 2.5 & 1.0 & + & 1.2 & + & 1.5 & 1.0 \\
\hline Epilobium angustfolium & + & 4.8 & + & + & + & + & 7.5 & + & 1.2 & + & + & 3.7 & + & 3.8 & 4.8 \\
\hline Epilobiu mpalustre & + & + & + & + & + & + & + & + & + & + & + & + & + & + & + \\
\hline Equisetum arvense & 3.8 & + & 0.2 & + & + & 18.8 & 4.2 & + & 3.0 & + & 36.5 & 8.3 & 5.5 & 8.5 & + \\
\hline Equisetum palustre & + & + & + & + & + & + & + & + & + & + & + & + & + & + & + \\
\hline Festuca ovina & + & + & + & + & + & + & 1.3 & + & + & + & + & 1.7 & + & + & + \\
\hline Festuca rubra & & & & & & & & & & & + & + & + & + & + \\
\hline Gnaphalium uliginosum & + & + & + & + & + & + & + & + & + & + & + & + & + & + & + \\
\hline Juncus arcticulatus & 9.0 & 7.0 & + & 3.0 & + & 16.8 & 14.2 & 2.0 & 3.0 & + & 13.6 & 10.8 & 1.7 & 3.3 & + \\
\hline Juncus bufonius & + & + & + & 3.3 & + & + & + & + & 2.0 & + & + & + & + & 2.5 & + \\
\hline Juncus filiformis & + & + & + & + & + & + & + & + & + & + & + & + & + & + & + \\
\hline Leontodon autumnalis & + & + & + & + & + & + & + & + & + & + & + & + & 3.0 & + & + \\
\hline Phleum pratense & + & + & + & + & + & + & + & + & + & + & + & + & + & + & + \\
\hline Plantago major & & & & & & & & & & & + & + & + & + & + \\
\hline Poa compressa & + & 1.0 & + & + & + & + & 1.0 & + & + & + & + & 1.0 & + & + & + \\
\hline Poa pratensis & & & & & & & & & & & + & + & + & 3.3 & + \\
\hline Polygonum aviculare & & & & & & + & + & + & + & 1.0 & + & + & + & + & 3.5 \\
\hline Rumex acetosa & + & + & + & + & + & + & 1.2 & + & + & + & + & 2.5 & + & + & + \\
\hline Solidago virgaurea & & & & & & & & & & & + & + & + & + & + \\
\hline Tussilago farfara & + & 6.8 & + & + & + & + & 14.5 & 1.7 & 8.3 & + & + & 9.3 & 4.2 & 17.5 & 3.7 \\
\hline \multicolumn{16}{|l|}{ Bottom layer } \\
\hline Cladonia deformis & + & + & + & + & + & + & + & + & + & + & + & + & + & + & + \\
\hline Dicranellacerviculata & + & 1.3 & 18.5 & 5.2 & 6.2 & + & 2.2 & 11.7 & 10.2 & 9.2 & + & 2.2 & 8.3 & 11.7 & 14.2 \\
\hline Marchantia polymorpha & + & + & + & + & + & + & + & + & 3.8 & 2.0 & + & 3.5 & + & 3.8 & + \\
\hline Pohlia nutans & 2.1 & 20.5 & 3.8 & 16.3 & 10.7 & 2.8 & 45.8 & 4.3 & 57.5 & 28.7 & 3.5 & 60.8 & 5.8 & 66.7 & 50.3 \\
\hline Polytrichum strictum & + & + & + & + & + & + & 1.8 & + & + & + & + & 4.5 & + & 1.2 & + \\
\hline
\end{tabular}

(ash, mounding, mounding + levelling + ash, mounding + ash) in 2013 was 0.12, 0.19, 0.18, 0.24 and $0.23 \mathrm{~g}$ $\mathrm{CO}_{2} \mathrm{~m}^{-2} \mathrm{~h}^{-1}$, respectively (Figure 5). The corresponding values for 2014 were $0.10,0.17,0.13,0.24$ and $0.19 \mathrm{~g}$ $\mathrm{CO}_{2} \mathrm{~m}^{-2} \mathrm{~h}^{-1}$, respectively (Figure 5). The difference between the $\mathrm{CO}_{2}$-effluxes of the treatments was significant 


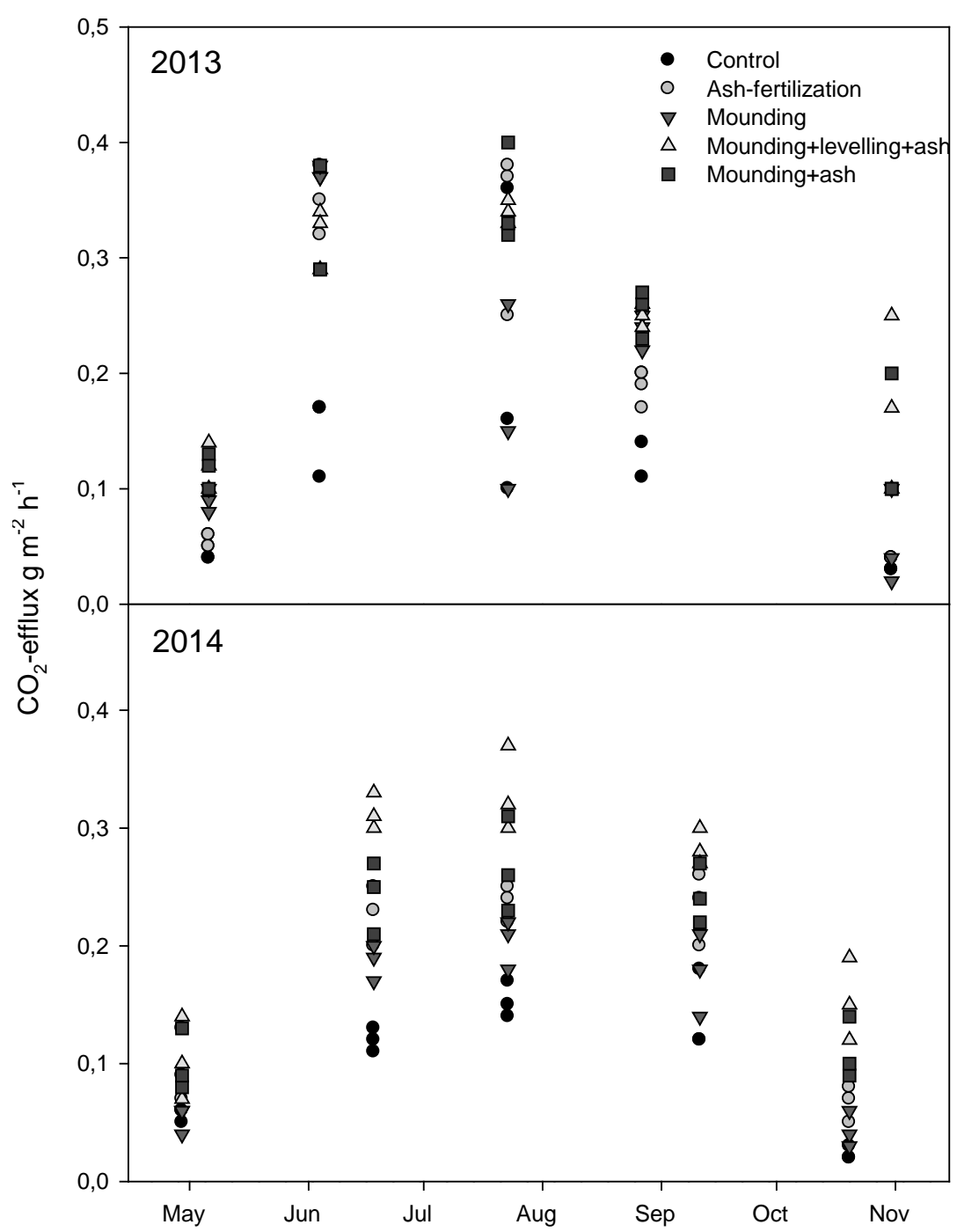

Figure 5. Measured instantaneous CO2-effluxes of the different soil amelioration treatments at Piipsanneva during 2013-2014.

both in $2013(\mathrm{~F}=2.99, p<0.05)$ and in $2014(\mathrm{~F}=7.00, p<0.05)$.

The most intense soil amelioration treatment (mounding + levelling + ash) showed the highest seasonal SR in both study years 2013 and 2014 (336 and $312 \mathrm{~g} \mathrm{CO}_{2}-\mathrm{C} \mathrm{m}^{-2}$, respectively) (Figure 5) based on simulations with SR-models and continuous weather data. The difference was clear compared to the other soil amelioration treatments particularly in 2014 (Figure 6). Simulated seasonal SR was the lowest in control site in both study years (175 and $125 \mathrm{~g} \mathrm{CO}_{2}-\mathrm{C} \mathrm{m}^{-2}$, respectively) (Figure 6). In general, all simulated seasonal SRs, except the SR of the most intense treatment (mounding + levelling + ash) were markedly but not significantly $(\mathrm{F}=4.04, p=$ 0.079) lower in 2014 than in 2013 (Figure 6).

\section{Discussion}

Mechanical peat extraction, lasting usually 20 - 50 years causes a long-lasting environmental disturbance of mire ecosystems. The remaining cutaway peatland has no vegetation or seed bank [18] [33] [42] [43]. Natural vegetation succession of cutaway peatlands is extremely slow process due to nutrient deficiencies and imbalances and the loose peat surface [44] [45] and abandoned sites can still after 20 years consist of mainly bare peat surface [43]. Our results confirmed the rather poor ability of cutaway peatlands to recover after peat extraction has ceased (see e.g. Triisberg et al. [14]). However, our study shows that the formation of ground vegetation on 


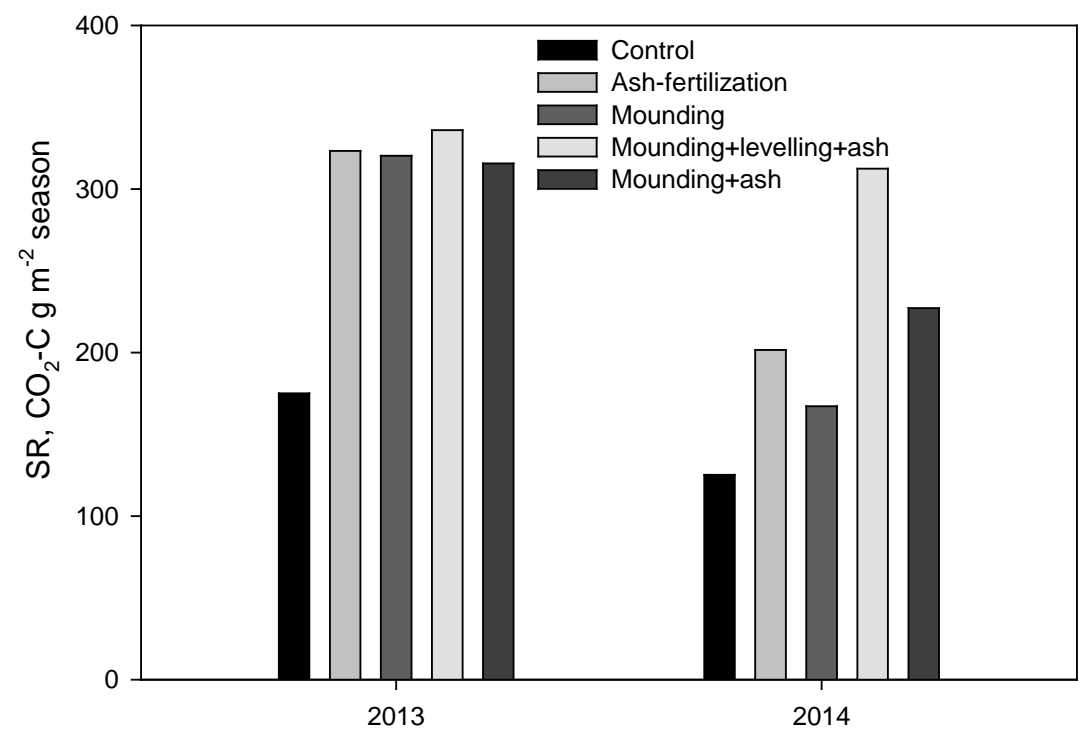

Figure 6. Simulated seasonal SR of the different soil amelioration treatments at Piipsanneva during 2013-2014.

a cutaway peatland can be enhanced significantly by soil amelioration, especially by ash-fertilization. Also previous studies have shown that active measures, such as blocking ditches for rewetting and spreading Sphagnum diaspores [46] [47] or fertilization [18] [33] are needed for successful vegetation of cutaway peatlands.

In our study, the most striking differences in moss coverage formation were observed between the unfertilized control and treatments fertilized with ash. However mere mounding had only a minor effect on coverage of mosses. Our results confirm the results of Huotari et al. [18] on the superior effect of ash (and PK-fertilizers as well) on moss cover formation on a cutaway peatland. On peatlands drained for forestry ash-fertilizer application has been reported causing large changes in the species composition of mosses [24] [25] [48]. However, results from peatland forests cannot be applied to cutaway peatlandssince the peat surface, with exception of drainage ditches, after cessation of peat extraction is completely devoid of plants and the environmental conditions are rather unfavorable for plant colonization [18] [33]. In cutaway peatlands vegetation succession usually begins in the ditches and on their banks [14]. Thus, although the immigration potential of mosses onto extracted peatlands is relatively high, colonization is, however, usually very scarce [49], indicating that factors other than spore supply restrict moss colonization [18] [33]. In many studies the availability of mineral nutrients, in particular $\mathrm{P}$, is reported to have had a crucial effect on both plant coverage and species composition of the early-successional stage of extracted peatlands [44] [50] [51]. Additionally, there may be also other compounds besides mineral nutrients in ash that promote germination of pioneer plants, since even ten-fold coverage of pioneer mosses have been observed on ash-fertilized areas compared to the areas with PK-fertilizer application [18]. These compounds are comparable to those present in plant-derived smoke which are known to facilitate the early establishment of pioneer plant species [52]. In fact, the colonization of ash-fertilized cutaway peatlands by mosses seems to resemble the process after severe forest fires [18].

In addition to mosses, especially two dominant vascular weed species (Alopecurus geniculatus and Equisetum arvense) became more abundant due to the ash-fertilizationin our study. However, the differences in weed coverage observed between the unfertilized control and treatments fertilized with ash were not as large as the difference of mosses, and mere mounding caused even the clear decrease of vascular plant coverage. Thus, ashfertilization seems to be the indisputable key soil amelioration measure that ensures the fast establishment of vegetation, both vascular plants and mosses, whereas measures where no mineral nutrients are added seem to be rather futile at least in short term on cutaway peatlands. The rapid colonization and establishment of ground vegetation may also facilitate the colonization of tree seedlings [18] [53]. However, on nutrient-rich soils dense weed vegetation may also have negative effects on the growth of other plants, and thus monotonize the plant community of cutaway peatlands [54].

In our two-year study the inter-annual variability in climatic conditions was considerable. For instance, the 
growing season in 2013 was clearly warmer than the long term average of 1984-2014 but instead the growing season in 2014 was very close to the average. Additionally, the precipitation in June 2013 was clearly higher than the monthly long term average of 1984-2014. As SR is highly temperature-sensitive [32] [38] [39] [55], year-to-year differences in seasonal temperatures between growing seasons of 2013 and 2014 probably contributed to the higher observed SR results in 2014. Our study showed that soil amelioration by mounding or adding ash increased SR considerably on cutaway peatland, in 2013 by ca. 90\%. Similarly, in the study of Moilanen et al. [30] made in Scots pine peatland forest, wood ash fertilization almost doubled the SR. However, mounding has not in short-term accelerated annual SR relative to the control treatmentin peatland forest regeneration areas [56].

In this study, only heterotrophic $\mathrm{CO}_{2}$-effluxes were measured, and only during the period of May-October. If we assume the proportion of the annual $\mathrm{CO}_{2}$-efflux emitted during the wintertime to be the same as in Mäkiranta et al. [32] (ca. 15\%) measured on an afforested cutaway peatland, our annual effluxes on control sites would be 144 - $201 \mathrm{~g} \mathrm{CO}_{2}-\mathrm{C} \mathrm{m}^{-2} \cdot \mathrm{y}^{-1}$ and 192 - $386 \mathrm{~g} \mathrm{CO}_{2}-\mathrm{C} \mathrm{m}^{-2} \mathrm{y}^{-1}$ on areas where soil amelioration treatments were made. In general, the annual SRs in our study roughly corresponded to those measured in other studies on afforested cutaway peatlands [32] or on the bare peat surfaces of peat extraction areas [57] [58]. For further comparison, also nutrient rich forestry-drained peatlands (Minkkinen et al. 2007; Ojanen et al. 2010) also emitted rather similar effluxes of $\mathrm{CO}_{2}$. However, $\mathrm{CO}_{2}$-emissions from nutrient-poor forestry-drained peatlands [38] [39] or from restored cutaway peatlands [59] were much lower than measured in our study. Why are the cutaway peatlands such large sources of $\mathrm{CO}_{2}$ ? They are disturbed, well-drained areas where bottom peat is well humified having shallow, often variable peat layer, which in this study was $10-20 \mathrm{~cm}$. Due to shallow peat layer, and mineral soil from the ditches, the ash content was very high (47\%) even on the control area when compared to peatland forests. The ash content increases near the surface of the mineral soil in peat profile [17]. Especially mineral soil in peatlands is closely related to the higher ash content [60] and higher pH [61] of surface peat, which may accelerate microbial activity and the decomposition of organic matter, and thus $\mathrm{CO}_{2}$-effluxes. Thus, due to marked differences in site characteristics results from peatlands forests cannot be directly applied to cutaway peatlands. Although there was no above-ground litter on SR measurement plots at the beginning of the experiment, the observed regrowth of plants on plots between measurements might imply some autotrophic activity in the soil, indicating that the $\mathrm{CO}_{2}$-effluxes from heterotrophic soil respiration may be overestimated in this study. Additionally, the growing vegetation may produce fresh carbon as a substrate for heterotrophic microbes, thereby directly increasing SR rate and also through priming impacts the decomposition rate of old peat [32]. However, since the $\mathrm{CO}_{2}$-efflux measurements were started almost immediately after the cessation of peat extraction, when the areas was without vegetation, the accumulation of fresh carbon and thus the priming impacts on decomposition were most probably negligible.

In order to derive the net ecosystem carbon exchange (NEE), it is necessary to also consider the carbon input via photosynthesis and carbon output via leaching. If the carbon bound by vegetation is taken into account, the carbon balance of the sites changes considerably. For instance, according to the eddy covariance measurements done by Lohila et al. [62], a 30-year old pine stand growing on an afforested field was only a minor source of atmospheric carbon (50 $\left.\mathrm{g} \mathrm{CO}_{2}-\mathrm{C} \mathrm{m}^{-2} \cdot \mathrm{y}^{-1}\right)$, and in a peatland forest it has been shown that adding wood ash as a fertilizer increased more $\mathrm{C}$ sequestration in the tree stand than $\mathrm{C}$ efflux from the peat [30]. Even though during the first years after ash application and afforestation ground vegetation exceeds tree seedlings as carbon stock [18], later the major C binding ecosystem components are trees. On cutaway peatlands dense downy birch stands have been shown to bind 200 - $280 \mathrm{~g}$ [63] and Scots pine stands $46-329 \mathrm{~g} \mathrm{CO}_{2}-\mathrm{C} \mathrm{m}^{-2} \cdot \mathrm{y}^{-1}$ [17] in their leafless above-ground biomass. If we assume root biomass to be $30 \%$ of the above-ground biomass [64], it would correspond total biomass $60-428 \mathrm{~g} \mathrm{CO}_{2}-\mathrm{C} \mathrm{m}^{-2} \cdot \mathrm{y}^{-1}$. Thus, even though the SR following ash fertilization or soil preparation may occasionally exceed the carbon sequestration into growing tree stands, afforestation, however, mostly compensates the $\mathrm{CO}_{2}$-effluxes. Therefore when the afforestation is successful, cutaway peatlands would rather be sinks or only minor sources of carbon into the atmosphere. Since ash fertilization has a long-term effect on growth of trees and carbon sequestration, also studies of the longer term effects of ash-fertilization and soil preparation on SR are needed.

\section{Conclusions}

Soil amelioration measures, necessary for successful vegetation and afforestation on cutaway peat extraction areas, enhance the $\mathrm{CO}_{2}$-effluxes into the atmosphere. The reasons for this increase are ash fertilization and min- 
eral soil admixture in mounding, and thus enhanced soil microbial activity. However, even though the $\mathrm{CO}_{2}$-effluxes following ash fertilization or soil preparation may occasionally exceed the carbon sequestration into growing tree stands, afforestation seems mostly compensating the $\mathrm{CO}_{2}$-effluxes if we also take into consideration the below-ground biomass. Thus, adding wood ash as a fertilizer would increase more $\mathrm{C}$ sequestration in the tree stand than $\mathrm{C}$ efflux from the peat.

Soil amelioration measures, especially ash-fertilization, also ensure the colonization and establishment of vigorous ground vegetation on cutaway peatlands. Rapid colonization of the bare peat surface of particularly by moss and weed species has several advantages. A dense moss carpet stabilizes the loose peat surface efficiently, and may decrease erosion and leaching of nutrients and suspended solids into watercourses. A moss carpet also controls evaporation and balances the moisture fluctuations in peat by storing water during rain occasions to serve as a reservoir during dry periods. Furthermore, the accumulation of plant-derived litter into the soil also enhances the carbon sequestration of ash-fertilized cutaway peatlands. In conclusion, despite enhancing the $\mathrm{CO}_{2}$-effluxes into the atmosphere, ash-fertilization prevents cutaway peatlands to remain vegetationless waste lands for many decades.

\section{Acknowledgements}

Mr. Olli Reinikainen took part into the planning of the experiment, Mr. Jorma Issakainen organized the field trials and soil amelioration treatments, and Ms. Reetta Kolppanen carried out the vegetation monitoring. This study was carried out in cooperation with the former Finnish Forest Research Institute and the Vapo Ltd., which supported this study financially. We sincerely thank all those persons and organizations who contributed to this study.

\section{References}

[1] Paappanen, T. and Leinonen, A. (2010) Peat Industry in the Six EU Member States-Summary Report. VTT Research Report VTT-R-045-48-0, 26 p.

[2] (2014) Finnish Statistical Yearbook of Forestry. 428 p.

[3] Virtanen, K., Hänninen, P., Kallinen, R.L., Vartiainen, S., Herranen, T. and Jokisaari, R. (2003) Suomen Turvevarat 2000. Summary: The Peat Reserves of Finland in 2000. Geological Survey of Finland, Reports of Investigation No. 156.

[4] Savolainen, V. and Silpola, J. (2008) Energy from Peat. In: Korhonen, R., Korpela, L. and Sarkkola, S., Eds. Finland-Fenland. Research and Sustainable Utilisation of Mires and Peat. Finnish Peatland Society and Maahenki Ltd., Helsinki, 176-188.

[5] Orru, M. and Orru, H. (2008) Sustainable Use of Estonian Peat Reserves and Environmental Challenges. Estonian Journal of Earth Sciences, 57, 87-93. http://dx.doi.org/10.3176/earth.2008.2.04

[6] Ramst, R. and Orru, M. (2009) Eesti mahajäe tudturbatootmisalade taastaimestumine. Summary: The Regeneration of Estonian Abandoned Milled Peatlands. Eesti Põlevloodusvarad ja-jäätmed, 1, 6-7.

[7] Renou, F. and Farrell, E.P. (2005) Reclaiming Peatlands for Forestry: The Irish Experience. In: Stanturf, J. A. and Madsen, P., Eds., Restoration of Boreal and Temperate Forests, CRC Press, London, 541-557.

[8] Selin, P. (1999) Turvevarojen teollinen käyttö ja suonpohjien hyödyntäminen Suomessa. Summary: Industrial Use of Peatlands and the Re-Use of Cutaway Areas in Finland. Jyväskylä Studies in Biological and Environmental Science No. 79, University of Jyväskylä, Jyväskylä, 239 p.

[9] Hånell, B., Svensson, J. and Magnusson, T. (1996) Efter-behandlingavtorvtäkter-enliteraturstudie med tonviktpåalternativetbeskogning. Summary: Reclamation of Peat Winning Fields-A Literature Review with Special Reference to the Establishment of Forest Stands. Reports in Forest Ecology and Forest Soils No. 70, Department of Forest Soils, Swedish University of Agricultural Sciences, Uppsala, 34 p.

[10] Kikamägi, K., Kuznetsova, T. and Ots, K. (2013) Effect of Wood Ash on the Biomass Production and Nutrient Status of Young Silver Birch (Betula pendula Roth) Trees on Cutaway Peatlands in Estonia. Ecological Engineering, 58, 1725. http://dx.doi.org/10.1016/j.ecoleng.2013.06.014

[11] Jylhä, P., Hytönen, J. and Ahtikoski, A. (2015) Profitability of Short-Rotation Biomass Production on Downy Birch Stands on Cut-Away Peatlands in Northern Finland. Biomass and Bioenergy, 75, 272-281. http://dx.doi.org/10.1016/j.biombioe.2015.02.027

[12] Kaunisto, S. (1997) Peatland Forestry in Finland: Problems and Possibilities from the Nutritional Point of View. 
Northern Forested Wetlands. In: Trettin, C.C., Jurgensen, M.F., Grigal, D.F., Gale, M.R. and Jeglum, J.K., Eds., Ecology and Management, Springer-Verlag, Berlin, 387-401.

[13] Aro, L., Kaunisto, S. and Saarinen, M. (1997) Suopohjienmetsitys. Hankeraportti 1986-1995. Summary: Afforestation of Peat Cutaway Areas. Project Report in 1986-1995. The Finnish Forest Research Institute, Research Papers 634, $1-51$.

[14] Triisberg, T., Karofeld, E. and Paal, J. (2011) Re-Vegetation of Block-Cut and Milled Peatlands: An Estonian Example. Mires and Peat, 8, 1-14.

[15] Kaunisto, S. (1987) Lannoituksen ja maanmuokkauksen vaikutus männyn ja rauduskoivun istutustaimien kasvuun suonpohjilla. Summary: Effect of Fertilization and Soil Preparation on the Development of Scots Pine and Silver Birch Plantations on Peat Cut-Over Areas. Folia Forestalia, 681, 1-23.

[16] Hytönen, J. and Kaunisto, S. (1999) Effects of Fertilization on the Biomass Production of Coppiced Mixed Birch and Willow Stands on a Cut-Away Peatland. Biomass and Bioenergy, 17, 455-469. http://dx.doi.org/10.1016/S0961-9534(99)00061-6

[17] Aro, L. and Kaunisto, S. (2003) Effect of Refertilisation and Growing Density on the Nutrition, Growth and Root Development of Young Scots Pine Stands in a Peat Cutaway Area with Deep Peat Layers. Suo, 54, 49-68. [In Finnish with English Summary]

[18] Huotari, N., Tillman-Sutela, E. and Kubin, E. (2009) Ground Vegetation Exceeds Tree Seedlings in Early Biomass Production and Carbon Stock on an Ash-Fertilized Cut-Away Peatland. Biomass and Bioenergy, 33, 1108-1115. http://dx.doi.org/10.1016/j.biombioe.2009.05.009

[19] Hytönen, J. (1994) Effect of Fertilizer Application Rate on Nutrient Status and Biomass Production in Short-Rotation Plantations of Willows on Cut-Away Peatland Areas. Suo, 45, 65-77.

[20] Hytönen J. (1996) Biomass Production and Nutrition of Short-Rotation Plantations. Research Papers 586, The Finnish Forest Research Institute, 1-61.

[21] Aro, L. (2000) Root Penetration of Scots Pine and Silver Birch on Cut-Away Peatlands. Sustaining Our Peatlands: Proceedings of the 11th International Peat Congress, Quebec City, 6-12 August 2000, 932-936.

[22] Huotari, N., Tillman-Sutela, E., Moilanen, M. and Laiho, R. (2015) Recycling of Ash-For the Good of the Environment? Forest Ecology and Management, 348, 226-240. http://dx.doi.org/10.1016/j.foreco.2015.03.008

[23] Silfverberg, K. (1996) Nutrient Status and Development of Tree Stands and Vegetation on Ash-Fertilized Drained Peatlands in Finland. The Finnish Forest Research Institute, Research Papers 588, 1-27.

[24] Silfverberg, K. and Hotanen, J.-P. (1989) Puuntuhkan pitkäaikaisvaikutukset ojitetulla mesotrofisella kalvakkanevalla Pohjois-Pohjanmaalla [Summary: Long-Term Effects of Wood-Ash on a Drained Mesotrophic Sphagnum papillosum Fen in Oulu District, Finland]. Folia Forestalia Polonica, 742, 1-23.

[25] Moilanen, M., Silfverberg, K. and Hokkanen, T. (2002) Effects of Wood-Ash on Tree Growth, Vegetation and Substrate Quality of a Drained Mire: Case Study. Forest Ecology and Management, 171, 321-338. http://dx.doi.org/10.1016/S0378-1127(01)00789-7

[26] Sikström, U., Almquist, C. and Jansson, G. (2010) Growth of Pinus sylvestris after the Application of Wood Ash or P and K Fertilizer to a Peatland in Southern Sweden. Silva Fennica, 44, 411-425. http://dx.doi.org/10.14214/sf.139

[27] Lukkala, O.J. (1951) Kokemuksia Jaakkoinsuo koe ojitus alueelta. Summary: Experiences from Jaakkoinsuo Experimental Drainage Area. Communicationes Instituti Forestalis Fenniae, 39, 1-53.

[28] Malmström, C. (1952) Svenska gödslingsförsök för belysande av de näringsekologiska villkoren för skogsväxt på torvmark. Communicationes Instituti Forestalis Fenniae, 40, 1-27. [In Swedish]

[29] Huikari, O. (1953) Tutkimuksia ojituksen ja tuhkalannoituksen vaikutuksesta eräiden soiden pieneliöstöön. Summary: Studies on the Effect of Drainage and Ash Fertilization upon the Microbes of Some Swamps. Communicationes Instituti Forestalis Fenniae, 42, 1-18.

[30] Moilanen, M., Hytönen, J. and Leppälä, M. (2012) The Effect of Wood Ash on Soil $\mathrm{CO}_{2}$ Emission and Carbon Stock of Tree Stand on a Drained Peatland-Case Study. European Journal of Soil Science, 63, 467-475. http://dx.doi.org/10.1111/j.1365-2389.2012.01467.x

[31] Tuittila, E.-S. and Komulainen, V.-M. (1995) Vegetation and $\mathrm{CO}_{2}$ Balance in an Abandoned Harvested Peatland in Aitoneva, Southern Finland. Suo, 46, 69-80.

[32] Mäkiranta, P., Hytönen, J., Aro, L., Maljanen, M., Pihlatie, M., Potila, H., Shurpali, N.J., Laine, J., Lohila,, A., Martikainen, P.J. and Minkkinen, K. (2007) Soil Greenhouse Gas Emissions from Afforested Organic Soil Croplands and Cutaway Peatlands. Boreal Environment Research, 12, 159-175.

[33] Huotari, N., Tillman-Sutela, E., Kauppi, A. and Kubin, E. (2006) Fertilization Ensures Rapid Formation of Ground Vegetation on Cut-Away Peatlands. Canadian Journal of Forest Research, 37, 874-883. 
http://dx.doi.org/10.1139/X06-292

[34] Hämet-Ahti, L., Suominen, J., Ulvinen, T. and Uotila, P. (1998) Retkeilykasvio. 4th Edition, Botanical Museum, Finnish Museum of Natural History, Helsinki.

[35] Koponen, T. (1994) Lehtisammalten määritysopas. 3rd Edition, Department of Botany, University of Helsinki, Helsinki.

[36] Jahns, H.M. (1996) Sanikkaiset, sammalet, jäkälät. Otava, Helsinki.

[37] Alm, J., Shurpali, N.J., Tuittila, E.-S., Laurila, T., Maljanen, M., Saarnio, S. and Minkkinen, K. (2007) Methods for Determining Emission Factors for the Use of Peat and Peatlands-Flux Measurements and Modeling. Boreal Environment Research, 12, 85-100.

[38] Minkkinen, K., Laine, J., Shurpali, N.J., Mäkiranta, P., Alm, J. and Penttilä, T. (2007) Heterotrophic Soil Respiration in Forestry Drained Peatlands. Boreal Environment Research, 12, 115-127.

[39] Ojanen, P., Minkkinen, K., Alm, J. and Penttilä, T. (2010) Soil-Atmosphere $\mathrm{CO}_{2}, \mathrm{CH}_{4}$ and $\mathrm{N}_{2} \mathrm{O}$ Fluxes in Boreal Forestry-Drained Peatlands. Forest Ecology and Management, 260, 411-421. http://dx.doi.org/10.1016/j.foreco.2010.04.036

[40] Lloyd, J. and Taylor, J.A. (1994) On the Temperature Dependence of Soil Respiration. Functional Ecology, 8, 315-323. http://dx.doi.org/10.2307/2389824

[41] Pan, W. and Connett, J.E. (2002) Selecting the Working Correlation Structure in Generalized Estimating Equations with Application to the Lung Health Study. Statistica Sinica, 12, 475-490.

[42] Salonen, V. (1987) Relationship between the Seed Rain and the Establishment of Vegetation in Two Areas Abandoned after Peat Harvesting. Ecography, 10, 171-174. http://dx.doi.org/10.1111/j.1600-0587.1987.tb00755.x

[43] Huopalainen, M., Tuittila, E.-S., Laine, J. and Vasander, H. (1998) Seed and Spore Bank in a Cutaway Peatland Twenty Years after Abandonment. International Peat Journal, 8, 42-51.

[44] Salonen, V. and Laaksonen, M. (1994) Effects of Fertilization, Liming, Watering and Tillage on Plant Colonization of Bare Peat Surfaces. Annales Botanici Fennici, 31, 29-36.

[45] Campbell, D.R., Lavoie, C. and Rochefort, L. (2002) Wind Erosion and Surface Stability in Abandoned Milled Peatlands. Canadian Journal of Soil Science, 82, 85-95. http://dx.doi.org/10.4141/S00-089

[46] Campeau, S., Rochefort, L. and Price, J.S. (2004) On the Use of Shallow Basins to Restore Cutover Peatlands: Plant Establishment. Restoration Ecology, 12, 471-482. http://dx.doi.org/10.1111/j.1061-2971.2004.00302.x

[47] Lavoie, C., Saint-Louis, A. and Lachance, D. (2005) Vegetation Dynamics on an Abandoned Vacuum-Mined Peatland: 5 Years of Monitoring. Wetlands Ecology and Management, 11, 97-107. http://dx.doi.org/10.1023/A:1022069808489

[48] Moilanen, M. and Silfverberg, K. (2004) Short-Term Effects of Wood-Ash on Two Drained Mires in Central Finland. Proceedings of the 12th International Peat Congress: Wise Use of Peatlands, Tampere, 6-11 June 2004, 464-471.

[49] Campbell, D.R., Rochefort, L. and Lavoie, C. (2003) Determining the Immigration Potential of Plants Colonizing Disturbed Environments: The Case of Milled Peatlands in Quebec. Journal of Applied Ecology, 40, 78-91. http://dx.doi.org/10.1046/j.1365-2664.2003.00782.x

[50] Reinikainen, A. (1964) Kasvillisuustutkimuksia Kivisuon rahkaturvealustaisilla lannoitusaloilla. Folia Forestalia, 6, 1-17. [In Finnish]

[51] Salonen, V. (1994) Revegetation of Harvested Peat Surfaces in Relation to Substrate Quality. Journal of Vegetation Science, 5, 43-48. http://dx.doi.org/10.2307/3235863

[52] Flematti, G.R., Ghisalberti, E.L., Dixon, K.V. and Trengove, R.D. (2004) A Compound from Smoke that Promotes Seed Germination. Science, 305, 977. http://dx.doi.org/10.1126/science.1099944

[53] Tuittila, E.-S., Rita, H., Vasander, H. and Laine, J. (2000) Vegetation Patterns around Eriophorum vaginatum L. Tussocks in a Cut-Away Peatland in Southern Finland. Canadian Journal of Botany, 78, 47-58. http://dx.doi.org/10.1139/b99-159

[54] Pöllänen, M. and Renou, F. (2002) Vegetation Development on Cutaway Peatlands Following Afforestation. Forest Ecosystem Research Group Reports 66, Department of Environmental Resource Management, University College, Dublin.

[55] Mäkiranta, P., Laiho, R., Fritze, H., Hytönen, J., Laine, J. and Minkkinen, K. (2009) Indirect Regulation of Heterotrophic Peat Soil Respiration by Water Level via Microbial Community Structure and Temperature Sensitivity. Soil Biology \& Biochemistry, 41, 695-703. http://dx.doi.org/10.1016/j.soilbio.2009.01.004

[56] Pearson, M., Saarinen, M., Minkkinen, K., Silvan, N. and Laine, J. (2012) Short-Term Impacts of Soil Preparation on Greenhouse Gas Fluxes: A Case Study in Nutrient-Poor, Clearcut Peatland Forest. Forest Ecology and Management, 283, 10-26. http://dx.doi.org/10.1016/j.foreco.2012.07.011 
[57] Nykänen, H., Silvola, J., Alm, J. and Martikainen, P.J. (1996) Fluxes of Greenhouse Gases $\mathrm{CO}_{2}, \mathrm{CH}_{4}$ and $\mathrm{N}_{2} \mathrm{O}$ on Some Peat Mining Areas in Finland. Publications of the Academy of Finland, 1/96, 141-147.

[58] Silvan, N., Silvan, K., Väisänen, S., Soukka, R. and Laine, J. (2012) Excavation-Drier Method of Energy-Peat Extraction Reduces Long-Term Climatic Impact. Boreal Environment Research, 17, 263-276.

[59] Tuittila, E.-S., Komulainen, V.-M., Vasander, H. and Laine, J. (1999) Restored Cut-Away Peatland as a Sink for Atmospheric $\mathrm{CO}_{2}$. Oecologia, 120, 563-574. http://dx.doi.org/10.1007/s004420050891

[60] Wall, A. and Hytönen, J. (1996) Effect of Mineral Soil Admixture on Nutrient Amounts of Afforested Peatland Fields. Suo, 47, 78-83. [In Finnish with English Summary]

[61] Pessi, Y. (1962) The pH Reaction of the Peat in Long-Term Soil Improvement Trials at the Leteensuo Experimental Station. Maataloustieteellinen Aikakauskirja, 34, 44-54. [In Finnish]

[62] Lohila, A., Laurila, T., Aro, L., Aurela, M., Tuovinen, J.-P., Laine, J., Kolari, P. and Minkkinen, K. (2007) Carbon Dioxide Exchange above a 30-Year-Old Scots Pine Plantation Established on Organic-Soil Cropland. Boreal Environment Research, 12, 141-157.

[63] Hytönen, J. and Aro, L. (2012) Biomass and Nutrition of Naturally Regenerated and Coppiced Birch on Cutaway Peatland during 37 Years. Silva Fennica, 46, 377-394. http://dx.doi.org/10.14214/sf.48

[64] Finér, L. (1989) Biomass and Nutrient Cycle in Fertilized and Unfertilized Pine, Mixed Birch and Pine and Spruce Stands on a Drained Mire. Acta Forestalia Fennica, 208, 1-63. 